\title{
ATTITUDE OF THE INVESTORS ON INVESTMENT IN COLATERAL SECURITIES OF CEMENT INDUSTRIES
}

\author{
Dr. S. Pounsamy \\ Assistant Professor, Department of Commerce, \\ Nandha Arts and Science College, Erode, India \\ Dr. P. Mohanraj \\ Associate Professor, Department of Management, \\ Nandha Arts and Science College, Erode, India
}

\begin{abstract}
Investment is the economic decision of committing a set of fixed monetary resources with the expectation of receiving a stream of returns over a reasonable long period of time in the future. Since the decision to invest in securities is revocable, investment ends are momentary and investment environment is fluctuating, the reliable bases for reasoned expectation become more and more ambiguous as one envisages of the distant future. Investment is concerned with the purchase and sale of financial assets and an attempt of the investor to make logical decisions about the various alternatives in order to earn suitable return. The present study aimed to know the attitude of the investors in securities of cement industries in major cities of Tamil Nadu.
\end{abstract}

Key word: Investment, Expectation, Revocable, Reliable, Logical

Cite this Article: Dr. S. Pounsamy and Dr. P. Mohanraj, Attitude of the Investors on Investment in Colateral Securities of Cement Industries, International Journal of Management, 10 (5), 2019, pp. 1-10.

$\mathrm{http}: / /$ iaeme.com/Home/issue/IJM?Volume $=10 \&$ Issue $=5$

\section{INTRODUCTION}

Collateral is a security in the form of an asset or property offered against a loan. Financial institutions require collateral for mortgages and other secured loans, including foreclosure, nonrecourse loans, and repossession. If the borrower stops making payments, the financial institution can take possession of the home or vehicle pledged. The collateral can be equal to, less, or greater than the value of the loan. This depends on many factors, including credit score, income, and how liquid the asset is. Applicants can pledge anything of value, including real estate, vehicles, inventory, stocks and bonds, and equipment. Intangible and tangible properties are accepted by financial institutions. Tangible properties include machinery and equipment, fixtures, annuities, art, jewelry, etc. Intangible properties include investment funding, chattel paper, and payment rights. Collateral securities include equity shares, preference shares, 
convertible debentures, non-convertibles debenture, public sector bonds, savings certificates, etc. equity shares and public sector bonds which are the most common investment avenues among the financial securities for the common man. This study aimed to know the attitude of the investors in securities of cement industries in major cities of Tamil Nadu.

\section{MATERIALS AND METHODS}

Shinde and zanvar (2014) aimed to put on some knowledge about key factors that influence investment behavior and ways these factors impact investment risk tolerance and decision making process among men and women and among different age groups. The individuals may be equal in all aspects, but their behavior is different in same situation. The study concluded that the modern investor is a mature and adequately groomed person. In spite of the phenomenal growth in the security market and quality Initial Public Offerings (IPOs) in the market, the individual investors prefer investments according to their risk preference. Vaijayanthimala and Vijayakumar (2014) analyzed the trends of production, capacity utilization, sales and market share of selected companies of Indian cement industry. It is observed that all the selected companies revealed fluctuating trend of production, capacity utilization and market share during the study period. The projection of production of cement in India showed that all the selected companies have growing good market potential in our country. Chettinad Cement Corporation Limited, Shree Cement Limited, Dalmia Cement Limited and Birla Corporation Limited also showed better performance with regard to their capacity utilization. The sales of all the selected companies marked a rising trend throughout the study period. The projection of sales of cement in India revealed that Grasim Industries Limited and Associated Cement Companies Limited have a fast emerging, growing market in the years to come in India. The analysis of company wise dispersion in market shares of Indian cement industry revealed that the mean rates of market share vary greatly in the case of all the companies. Vijaya (2014) stated that due to extreme volatility in the stock markets, understanding the individual investor behaviour is very important because the decisions of investors in the stock market play an important role in defining the market trend, which then influence the country economy. It is also very important for market regulators, policy makers, financial planners as well as managers of a firm because how an individual investor respond to market movements would help them in devising appropriate asset allocation strategies for their clients.

The present study used both primary as well as secondary data. The primary data was collected from the investors of collateral securities in major cities of Tamil Nadu. Field survey technique was employed to collect the pertinent data from the 660 selected sample respondents in Erode district. The respondents were selected by using simple random sampling method from the selected area. Questionnaire was the main tool for collecting the data. The secondary data was also collected for the study. The data thus collected from the primary sources were arranged in the simple tabular statements. Cluster analysis was used for the further analysis.

\section{RESULTS AND DISCUSSIONS}

Cluster analysis is a multivariate statistical technique which groups unknown number of persons / objects / occasions into groups such that the members of each group are having similar characteristics / attributes. The primary objective of Cluster Analysis is to define the structure of the data and identifying the most similar observations to place them into groups. This analysis is applied to a large set of data which may consist of many variables. Cluster analysis determines internal homogeneity. i.e., similarities exist among the respondents or items and external heterogeneity i.e., the differences exist between different groups of respondents or items. This analysis helps in grouping the objects or persons based on the variables considered in this analysis. The sample selected for cluster analysis included the respondents' opinion on their 
level of attitude towards investment in collateral securities of cement industries. The researcher took the sample of 660 respondents with various demographic characteristics in major cities of Tamil Nadu. In the clustering procedure hierarchical clustering method was adopted for first stage. In this method, agglomerative method was used with Average linkage between groups method. As the agglomeration schedule for 660 cases was very large, the values from last 20 cases were given in the table.

Table 1 Agglomeration Schedule

\begin{tabular}{|c|c|c|c|c|c|c|}
\hline \multirow[t]{2}{*}{ Stage } & \multicolumn{2}{|c|}{ Cluster Combined } & \multirow[t]{2}{*}{ Coefficients } & \multicolumn{2}{|c|}{$\begin{array}{c}\text { Stage Cluster First } \\
\text { Appears }\end{array}$} & \multirow{2}{*}{$\begin{array}{l}\text { Next } \\
\text { Stage }\end{array}$} \\
\hline & Cluster 1 & Cluster 2 & & Cluster 1 & Cluster 2 & \\
\hline 641 & 4 & 648 & 73.903 & 639 & 0 & 646 \\
\hline 642 & 11 & 217 & 74.667 & 635 & 0 & 658 \\
\hline 643 & 12 & 190 & 75.000 & 594 & 0 & 646 \\
\hline 644 & 1 & 496 & 76.117 & 638 & 0 & 648 \\
\hline 645 & 19 & 34 & 77.000 & 557 & 611 & 650 \\
\hline 646 & 4 & 12 & 77.219 & 641 & 643 & 647 \\
\hline 647 & 4 & 100 & 77.813 & 646 & 636 & 649 \\
\hline 648 & 1 & 3 & 78.229 & 644 & 54 & 656 \\
\hline 649 & 4 & 102 & 78.920 & 647 & 633 & 650 \\
\hline 650 & 4 & 19 & 81.282 & 649 & 645 & 652 \\
\hline 651 & 230 & 321 & 84.000 & 0 & 0 & 656 \\
\hline 652 & 4 & 210 & 84.910 & 650 & 640 & 653 \\
\hline 653 & 4 & 75 & 86.545 & 652 & 618 & 654 \\
\hline 654 & 4 & 8 & 86.804 & 653 & 612 & 655 \\
\hline 655 & 4 & 576 & 90.500 & 654 & 0 & 658 \\
\hline 656 & 1 & 230 & 93.424 & 648 & 651 & 657 \\
\hline 657 & 1 & 31 & 95.726 & 656 & 627 & 659 \\
\hline 658 & 4 & 11 & 103.004 & 655 & 642 & 659 \\
\hline 659 & 1 & 4 & 116.883 & 657 & 658 & 0 \\
\hline
\end{tabular}

Table No. 1 shows the agglomeration schedule of the cluster analysis. In the agglomeration schedule, the figures from top to bottom (stage 1 to 659) indicates the sequence in which the cases get combined with other until all 660 cases are combined together in one cluster at the last stage (stage 659). To identify the number of clusters, the co-efficient values (i.e difference between rows) in column 4 is considered. The figures of co-efficient values were seen from the last row upwards to have the lowest possible number of clusters for interpretation. The difference in the value of co-efficients from stage 19 and 18 is 13.879 (116.883 - 103.004) indicating the one cluster. The procedure is continued till the differences between the two stages get reduced in order to identify the number of clusters. In the next stage, the difference between stage 18 and 17 is 7.278 (103.004 - 95.726) which is high. The difference between 17 and 16 is 2.302 (95.726 - 93.424) indicating a decreasing trend and the difference between 16 and 15 is 2.924 (93.424 - 90.500) indicating a decreasing trend. The difference between 15 and 14 is 3.696 (90.500 - 86.804) indicating a decreasing trend. Again there is a decreasing trend in the difference between 14 and 13 is $0.259(86.804-86.545)$. But, the difference between stages 13 and 12 is $1.635(86.545-84.910)$ indicating an increasing trend and in stages 12 and 11 the difference is $0.910(84.910-84.000)$ showing again a decreasing trend. The first difference of 13.879 is ignored because it would indicate only one cluster in the data, the next largest difference 7.278 indicating a three cluster solution. It was decided consequently to have three clusters from the agglomeration schedule. After deciding the number of clusters as three, the non-hierarchical k-means (quick clustering) clustering method was used to find out the statements pertaining to the attitude of the respondents towards investment in collateral 
securities of cement industries on each cluster. The output initial cluster centers, final cluster centers and ANOVA tables are interpreted to decide the variables in each cluster. Table No. 2 shows the initial cluster formation for 20 variables selected with their mean scores.

Table 2 Initial Cluster Centers

\begin{tabular}{|c|c|c|c|c|}
\hline \multirow{2}{*}{$\begin{array}{l}\text { Va. } \\
\text { No. }\end{array}$} & \multirow{2}{*}{ Statements } & \multicolumn{3}{|c|}{ Cluster } \\
\hline & & 1 & 2 & 3 \\
\hline 1 & I usually invest in cement companies which I know and trust & 1 & 1 & 4 \\
\hline 2 & I use past price movement to predict future price & 1 & 1 & 5 \\
\hline 3 & My investment is based on the market position & 1 & 1 & 5 \\
\hline 4 & $\begin{array}{l}\text { I feel that periodic review on financial performance of the company is } \\
\text { necessary for putting investment }\end{array}$ & 5 & 5 & 5 \\
\hline 5 & I make investment decision on the basis of company's dividend ratio & 1 & 1 & 5 \\
\hline 6 & Betterment of agent services may attract me to invest towards the schemes & 1 & 5 & 5 \\
\hline 7 & $\begin{array}{l}\text { I am comfortable with information provided by cement industries on their } \\
\text { collateral securities }\end{array}$ & 5 & 1 & 5 \\
\hline 8 & I put money in collateral securities of cement industries only to save tax & 1 & 5 & 5 \\
\hline 9 & $\begin{array}{l}\text { Irrespective of inflation I will put money in fixed income securities of } \\
\text { cement industries }\end{array}$ & 1 & 1 & 5 \\
\hline 10 & My investment decision has changed over period of time & 1 & 5 & 5 \\
\hline 11 & $\begin{array}{l}\text { Adequate and reliable portfolio management services are essential to my } \\
\text { investment }\end{array}$ & 5 & 1 & 5 \\
\hline 12 & I am well informed about the collateral securities of cement industries & 1 & 5 & 5 \\
\hline 13 & $\begin{array}{l}\text { I know that there is a small but positive relationship between corporate } \\
\text { social performance and company financial performance }\end{array}$ & 5 & 1 & 5 \\
\hline 14 & $\begin{array}{l}\text { A proper investment plan considers my personal circumstances, objectives } \\
\text { and risk tolerance }\end{array}$ & 1 & 5 & 4 \\
\hline 15 & $\begin{array}{l}\text { Establishing a better relationship with a financial advisor, I can make a } \\
\text { better decision on my investment }\end{array}$ & 5 & 1 & 5 \\
\hline 16 & $\begin{array}{l}\text { Always I consider the cash flow of cement industries before making an } \\
\text { investment of securities }\end{array}$ & 1 & 2 & 4 \\
\hline 17 & $\begin{array}{l}\text { Financial performance of the cement industries guide in choosing the right } \\
\text { types of investments to fit my needs, personality and goals }\end{array}$ & 5 & 1 & 5 \\
\hline 18 & $\begin{array}{l}\text { I believe that it is possible to manage income more effectively through better } \\
\text { investment planning }\end{array}$ & 2 & 3 & 5 \\
\hline 19 & $\begin{array}{l}\text { The investment in collateral securities created from good planning can prove } \\
\text { beneficial in difficult times }\end{array}$ & 1 & 1 & 5 \\
\hline 20 & $\begin{array}{l}\text { Betterment of financial performance of cement industry may attract more } \\
\text { investors towards the collateral securities }\end{array}$ & 2 & 2 & 5 \\
\hline
\end{tabular}


Table No. 3 shows the final cluster formation for 20 variables selected with their mean scores.

Table 3 Final Cluster Centers

\begin{tabular}{|c|c|c|c|c|}
\hline \multirow{2}{*}{$\begin{array}{l}\text { Va. } \\
\text { No. }\end{array}$} & \multirow{2}{*}{ Statements } & \multicolumn{3}{|c|}{ Cluster } \\
\hline & & 1 & 2 & 3 \\
\hline 1 & I usually invest in cement companies which I know and trust & 2 & 3 & 3 \\
\hline 2 & I use past price movement to predict future price & 2 & 3 & 3 \\
\hline 3 & My investment is based on the market position & 2 & 3 & 3 \\
\hline 4 & $\begin{array}{l}\text { I feel that periodic review on financial performance of the company is } \\
\text { necessary for putting investment }\end{array}$ & 3 & 4 & 5 \\
\hline 5 & I make investment decision on the basis of company's dividend ratio & 2 & 4 & 4 \\
\hline 6 & Betterment of agent services may attract me to invest towards the schemes & 2 & 4 & 4 \\
\hline 7 & $\begin{array}{l}\text { I am comfortable with information provided by cement industries on their } \\
\text { collateral securities }\end{array}$ & 2 & 4 & 5 \\
\hline 8 & I put money in collateral securities of cement industries only to save tax & 2 & 4 & 4 \\
\hline 9 & $\begin{array}{l}\text { Irrespective of inflation I will put money in fixed income securities of } \\
\text { cement industries }\end{array}$ & 2 & 4 & 4 \\
\hline 10 & My investment decision has changed over period of time & 2 & 4 & 5 \\
\hline 11 & $\begin{array}{l}\text { Adequate and reliable portfolio management services are essential to my } \\
\text { investment }\end{array}$ & 2 & 4 & 4 \\
\hline 12 & I am well informed about the collateral securities of cement industries & 2 & 4 & 4 \\
\hline 13 & $\begin{array}{l}\text { I know that there is a small but positive relationship between corporate } \\
\text { social performance and company financial performance }\end{array}$ & 2 & 4 & 4 \\
\hline 14 & $\begin{array}{l}\text { A proper investment plan considers my personal circumstances, objectives } \\
\text { and risk tolerance }\end{array}$ & 2 & 3 & 5 \\
\hline 15 & $\begin{array}{l}\text { Establishing a better relationship with a financial advisor, I can make a } \\
\text { better decision on my investment }\end{array}$ & 2 & 4 & 5 \\
\hline 16 & $\begin{array}{l}\text { Always I consider the cash flow of cement industries before making an } \\
\text { investment of securities }\end{array}$ & 2 & 3 & 4 \\
\hline 17 & $\begin{array}{l}\text { Financial performance of the cement industries guide in choosing the right } \\
\text { types of investments to fit my needs, personality and goals }\end{array}$ & 2 & 4 & 5 \\
\hline 18 & $\begin{array}{l}\text { I believe that it is possible to manage income more effectively through } \\
\text { better investment planning }\end{array}$ & 2 & 3 & 4 \\
\hline 19 & $\begin{array}{l}\text { The investment in collateral securities created from good planning can prove } \\
\text { beneficial in difficult times }\end{array}$ & 2 & 3 & 5 \\
\hline 20 & $\begin{array}{l}\text { Betterment of financial performance of cement industry may attract more } \\
\text { investors towards the collateral securities }\end{array}$ & 2 & 3 & 4 \\
\hline
\end{tabular}

The final cluster centers given in Table No. 3 contain the mean values for each variable in each cluster. As the data is scaled scoring with the scores 5 to 1, (i.e. 5-Strongly Agree, 4Agree, 3-Neutral, 2-Disagree, 1-Strongly Disagree), the variables for which the mean values with scores more than 3 were being selected in each cluster which was equivalent to the neutral opinion on the attitude of the respondents towards investment in collateral securities of cement industries. The number of respondents in each cluster segment is shown in Table No. 4.

Table 4 Number of Cases in Each Cluster

\begin{tabular}{|l|c|}
\hline Cluster 1 (Massive attitude) & 236.000 \\
\hline Cluster 2 (Strider attitude) & 193.000 \\
\hline $\begin{array}{l}\text { Cluster 3 } \\
\text { (Disgusted attitude) }\end{array}$ & 231.000 \\
\hline Valid & 660 \\
\hline Missing & 0 \\
\hline
\end{tabular}


Table No. 4 shows the number of respondents in each cluster out of the 660 respondents. The first cluster was grouped by 236 respondents $(35.75 \%)$ and named as massive attitude, second cluster was grouped by 193 respondents (29.24\%) and named as strider attitude and third cluster was grouped by 231 respondents $(35.00 \%)$ and named as disgusted attitude. The variables in each cluster segment was identified based on the mean values in the final cluster center table. The number of respondents in each cluster was also found as given in Table No. 5 .

Table 5 Cluster Formation with Variables and Mean Values

\begin{tabular}{|c|c|c|c|}
\hline Cluster & Va. No. & Statements & $\begin{array}{l}\text { Mean } \\
\text { Value }\end{array}$ \\
\hline I & 4 & $\begin{array}{l}\text { I feel that periodic review on financial performance of the } \\
\text { company is necessary for putting investment }\end{array}$ & 3 \\
\hline Cluster & Va. No. & Statements & $\begin{array}{l}\text { Mean } \\
\text { Value }\end{array}$ \\
\hline \multirow{18}{*}{ II } & 1 & I usually invest in cement companies which I know and trust & 3 \\
\hline & 2 & I use past price movement to predict future price & 3 \\
\hline & 3 & My investment is based on the market position & 3 \\
\hline & 4 & $\begin{array}{l}\text { I feel that periodic review on financial performance of the } \\
\text { company is necessary for putting investment }\end{array}$ & 4 \\
\hline & 5 & $\begin{array}{l}\text { I make investment decision on the basis of company's } \\
\text { dividend ratio }\end{array}$ & 4 \\
\hline & 6 & $\begin{array}{l}\text { Betterment of agent services may attract me to invest } \\
\text { towards the schemes }\end{array}$ & 4 \\
\hline & 7 & $\begin{array}{l}\text { I am comfortable with information provided by cement } \\
\text { industries on their collateral securities }\end{array}$ & 4 \\
\hline & 8 & $\begin{array}{l}\text { I put money in collateral securities of cement industries only } \\
\text { to save tax }\end{array}$ & 4 \\
\hline & 9 & $\begin{array}{l}\text { Irrespective of inflation I will put money in fixed income } \\
\text { securities of cement industries }\end{array}$ & 4 \\
\hline & 10 & My investment decision has changed over period of time & 4 \\
\hline & 11 & $\begin{array}{l}\text { Adequate and reliable portfolio management services are } \\
\text { essential to my investment }\end{array}$ & 4 \\
\hline & 12 & $\begin{array}{l}\text { I am well informed about the collateral securities of cement } \\
\text { industries }\end{array}$ & 4 \\
\hline & 13 & $\begin{array}{l}\text { I know that there is a small but positive relationship between } \\
\text { corporate social performance and company financial } \\
\text { performance }\end{array}$ & 4 \\
\hline & 14 & $\begin{array}{l}\text { A proper investment plan considers my personal } \\
\text { circumstances, objectives and risk tolerance }\end{array}$ & 3 \\
\hline & 15 & $\begin{array}{l}\text { Establishing a better relationship with a financial advisor, I } \\
\text { can make a better decision on my investment }\end{array}$ & 4 \\
\hline & 16 & $\begin{array}{l}\text { Always I consider the cash flow of cement industries before } \\
\text { making an investment of securities }\end{array}$ & 3 \\
\hline & 17 & $\begin{array}{l}\text { Financial performance of the cement industries guide in } \\
\text { choosing the right types of investments to fit my needs, } \\
\text { personality and goals }\end{array}$ & 4 \\
\hline & 18 & $\begin{array}{l}\text { I believe that it is possible to manage income more } \\
\text { effectively through better investment planning }\end{array}$ & 3 \\
\hline
\end{tabular}




\begin{tabular}{|c|c|c|c|}
\hline & 19 & $\begin{array}{l}\text { The investment in collateral securities created from good } \\
\text { planning can prove beneficial in difficult times }\end{array}$ & 3 \\
\hline & 20 & $\begin{array}{l}\text { Betterment of financial performance of cement industry may } \\
\text { attract more investors towards the collateral securities }\end{array}$ & 3 \\
\hline Cluster & Va. No. & Statements & $\begin{array}{l}\text { Mean } \\
\text { Value }\end{array}$ \\
\hline \multirow{20}{*}{ III } & 1 & I usually invest in cement companies which I know and trust & 3 \\
\hline & 2 & I use past price movement to predict future price & 3 \\
\hline & 3 & My investment is based on the market position & 3 \\
\hline & 4 & $\begin{array}{l}\text { I feel that periodic review on financial performance of the } \\
\text { company is necessary for putting investment }\end{array}$ & 5 \\
\hline & 5 & $\begin{array}{l}\text { I make investment decision on the basis of company's } \\
\text { dividend ratio }\end{array}$ & 4 \\
\hline & 6 & $\begin{array}{l}\text { Betterment of agent services may attract me to invest } \\
\text { towards the schemes }\end{array}$ & 4 \\
\hline & 7 & $\begin{array}{l}\text { I am comfortable with information provided by cement } \\
\text { industries on their collateral securities }\end{array}$ & 5 \\
\hline & 8 & $\begin{array}{l}\text { I put money in collateral securities of cement industries only } \\
\text { to save tax }\end{array}$ & 4 \\
\hline & 9 & $\begin{array}{l}\text { Irrespective of inflation I will put money in fixed income } \\
\text { securities of cement industries }\end{array}$ & 4 \\
\hline & 10 & My investment decision has changed over period of time & 5 \\
\hline & 11 & $\begin{array}{l}\text { Adequate and reliable portfolio management services are } \\
\text { essential to my investment }\end{array}$ & 4 \\
\hline & 12 & $\begin{array}{l}\text { I am well informed about the collateral securities of cement } \\
\text { industries }\end{array}$ & 4 \\
\hline & 13 & $\begin{array}{l}\text { I know that there is a small but positive relationship between } \\
\text { corporate social performance and company financial } \\
\text { performance }\end{array}$ & 4 \\
\hline & 14 & $\begin{array}{l}\text { A proper investment plan considers my personal } \\
\text { circumstances, objectives and risk tolerance }\end{array}$ & 5 \\
\hline & 15 & $\begin{array}{l}\text { Establishing a better relationship with a financial advisor, I } \\
\text { can make a better decision on my investment }\end{array}$ & 5 \\
\hline & 16 & $\begin{array}{l}\text { Always I consider the cash flow of cement industries before } \\
\text { making an investment of securities }\end{array}$ & 4 \\
\hline & 17 & $\begin{array}{l}\text { Financial performance of the cement industries guide in } \\
\text { choosing the right types of investments to fit my needs, } \\
\text { personality and goals }\end{array}$ & 5 \\
\hline & 18 & $\begin{array}{l}\text { I believe that it is possible to manage income more } \\
\text { effectively through better investment planning }\end{array}$ & 4 \\
\hline & 19 & $\begin{array}{l}\text { The investment in collateral securities created from good } \\
\text { planning can prove beneficial in difficult times }\end{array}$ & 5 \\
\hline & 20 & $\begin{array}{l}\text { Betterment of financial performance of cement industry may } \\
\text { attract more investors towards the collateral securities }\end{array}$ & 4 \\
\hline
\end{tabular}

To study which of the variables is statistically significant across the 3 clusters, ANOVA was employed and the result obtained is given in the table no. 6. 
Table 6 ANOVA

\begin{tabular}{|c|c|c|c|c|c|c|}
\hline \multirow[b]{2}{*}{ Variables } & \multicolumn{2}{|c|}{ Cluster } & \multicolumn{2}{|c|}{ Error } & \multirow[b]{2}{*}{$\mathbf{F}$} & \multirow[b]{2}{*}{ Sig. } \\
\hline & $\begin{array}{c}\text { Mean } \\
\text { Square }\end{array}$ & df & $\begin{array}{c}\text { Mean } \\
\text { Square }\end{array}$ & df & & \\
\hline $\begin{array}{l}\text { I usually invest in cement companies } \\
\text { which I know and trust }\end{array}$ & 27.128 & 2 & .978 & 657 & 27.747 & .000 \\
\hline $\begin{array}{l}\text { I use past price movement to predict } \\
\text { future price }\end{array}$ & 101.611 & 2 & 1.202 & 657 & 84.536 & .000 \\
\hline $\begin{array}{l}\text { My investment is based on the market } \\
\text { position }\end{array}$ & 83.012 & 2 & .971 & 657 & 85.490 & .000 \\
\hline $\begin{array}{l}\text { I feel that periodic review on financial } \\
\text { performance of the company is necessary } \\
\text { for putting investment }\end{array}$ & 214.140 & 2 & 1.429 & 657 & 149.851 & .000 \\
\hline $\begin{array}{l}\text { I make investment decision on the basis } \\
\text { of company's dividend ratio }\end{array}$ & 314.591 & 2 & 1.029 & 657 & 305.667 & .000 \\
\hline $\begin{array}{l}\text { Betterment of agent services may attract } \\
\text { me to invest towards the schemes }\end{array}$ & 334.412 & 2 & .921 & 657 & 363.052 & .000 \\
\hline $\begin{array}{l}\text { I am comfortable with information } \\
\text { provided by cement industries on their } \\
\text { collateral securities }\end{array}$ & 311.485 & 2 & 1.000 & 657 & 311.473 & .000 \\
\hline $\begin{array}{l}\text { I put money in collateral securities of } \\
\text { cement industries only to save tax }\end{array}$ & 318.710 & 2 & .998 & 657 & 319.296 & .000 \\
\hline $\begin{array}{l}\text { Irrespective of inflation I will put money } \\
\text { in fixed income securities of cement } \\
\text { industries }\end{array}$ & 397.238 & 2 & .980 & 657 & 405.523 & .000 \\
\hline $\begin{array}{l}\text { My investment decision has changed } \\
\text { over period of time }\end{array}$ & 356.101 & 2 & .996 & 657 & 357.567 & .000 \\
\hline $\begin{array}{l}\text { Adequate and reliable portfolio } \\
\text { management services are essential to my } \\
\text { investment }\end{array}$ & 312.851 & 2 & 1.089 & 657 & 287.382 & .000 \\
\hline $\begin{array}{l}\text { I am well informed about the collateral } \\
\text { securities of cement industries }\end{array}$ & 339.304 & 2 & 1.066 & 657 & 318.316 & .000 \\
\hline $\begin{array}{l}\text { I know that there is a small but positive } \\
\text { relationship between corporate social } \\
\text { performance and company financial } \\
\text { performance }\end{array}$ & 322.418 & 2 & 1.135 & 657 & 284.176 & .000 \\
\hline $\begin{array}{l}\text { A proper investment plan considers my } \\
\text { personal circumstances, objectives and } \\
\text { risk tolerance }\end{array}$ & 359.018 & 2 & .964 & 657 & 372.460 & .000 \\
\hline $\begin{array}{l}\text { Establishing a better relationship with a } \\
\text { financial advisor, I can make a better } \\
\text { decision on my investment }\end{array}$ & 414.406 & 2 & .919 & 657 & 451.156 & .000 \\
\hline $\begin{array}{l}\text { Always I consider the cash flow of } \\
\text { cement industries before making an } \\
\text { investment of securities }\end{array}$ & 388.768 & 2 & 1.109 & 657 & 350.655 & .000 \\
\hline $\begin{array}{l}\text { Financial performance of the cement } \\
\text { industries guide in choosing the right } \\
\text { types of investments to fit my needs, } \\
\text { personality and goals }\end{array}$ & 433.874 & 2 & 1.136 & 657 & 382.059 & .000 \\
\hline $\begin{array}{l}\text { I believe that it is possible to manage } \\
\text { income more effectively through better } \\
\text { investment planning }\end{array}$ & 289.277 & 2 & 1.145 & 657 & 252.730 & .000 \\
\hline
\end{tabular}




\begin{tabular}{|l|c|c|c|c|c|c|}
\hline $\begin{array}{l}\text { The investment in collateral securities } \\
\text { created from good planning can prove } \\
\text { beneficial in difficult times }\end{array}$ & 404.154 & 2 & 1.059 & 657 & 381.706 & .000 \\
\hline $\begin{array}{l}\text { Betterment of financial performance of } \\
\text { cement industry may attract more } \\
\text { investors towards the collateral securities }\end{array}$ & 292.468 & 2 & 1.228 & 657 & 238.222 & .000 \\
\hline
\end{tabular}

The Anova table helped to identify, which of the 20 statements were significant across the 3 clusters. The last column in the table indicates that all the statements are significant at 0.01 levels (equivalent to $99 \%$ confidence level) as they have probability values less than 0.01 .

The validity and stability of the clusters were checked by splitting the sample into two strata of 330 each and repeating the same procedure of cluster analysis in 2 stages (hierarchical and non-hierarchical). The results showed 3 cluster solutions on both the samples. From the analysis, it is inferred that three categories of the respondents derived from the cluster analysis based on the attitude towards investment in collateral securities of cement industries. The first cluster was grouped by 236 respondents $(35.75 \%)$ and named as massive attitude, second cluster was grouped by 193 respondents $(29.24 \%)$ and named as strider attitude and third cluster was grouped by 231 respondents $(35.00 \%)$ and named as disgusted attitude. Finally, it is concluded that most of the respondents are having high level (massive) attitude towards investment in collateral securities of cement industries. Anova table also proved that there is a significant relationship between selected variables and investors' attitude towards investment in collateral securities of cement industries.

\section{RECOMMENDATIONS AND CONCLUSION}

Most of the investors make a small size of investment in collateral securities of cement industries because information structure, financial performance of cement industry and the factors in the market systematically influence individuals' investment decisions as well as market outcomes. The Cement Industry in Tamil Nadu is currently in the throes of comparatively challenging times with relatively low consumption growth rates and an overbuilt capacity. Even though the industry may perform well, the companies in the that particular industry may suffer from lack of ability or any other factor, one should scrutinize the performance of the company, in considering importantly, leverages, betas, $\mathrm{P} / \mathrm{E}$ ratio, sales growth, and market to book ratios. Therefore, it is recommended that cement industries should concentrate more on their financial performance to attract new investors and they should publish their actual performance with financial indicators periodically. Hence, searching more suitable areas for developing industry is a need of the hour. Investors also have a lot of investment opportunities in collateral securities of cement industry. The investor has to find good among the alternatives. It is very difficult to find the good opportunity so they have to gain much knowledge on accounting information of the industry which helps the investors to find good one among the alternatives.

\section{REFERENCES}

[1] Arindam Ghosh, "Working Capital Management Practices in Some Selected Industries in India", The Management Accountant, Vol. 42, No. 4, 2007, pp. 60-67.

[2] Bhayani and Sanjay, J., "Determinant of Profitability in Indian Cement Industry", South Asian Journal of Management, Vol.17, No. 4, 2010, pp. 6-20.

[3] Burange, L.G., and Shruti Yamini, "Performance of Indian Cement Industry: the Competitive Landscape", The Journal of Finance, Vol.39, No.1, 2008, pp.127-145. 
Attitude of the Investors on Investment in Colateral Securities of Cement Industries

[4] Chandrasekaran. N., "Determinants of Profitability in Cement industry Decision", Vol.20, No. 4, 1993, pp. 235-244.

[5] Dr. Naveeta Mehta And Ms. Shilpa Dang, "Identification of Important Stock Investment Attributes Using Data Reduction Technique", International Journal of Computer Engineering and Technology (IJCET), Volume 3, Issue 2, July- September (2012), Pp. 188195.

[6] Pradosh Nath and Bose, P.R., "Leveraging Liberalization-The Case of Indian Cement Industry", Economic and Political Weekly, Vol. 37, Issue. 30, 2002, pp. 3199-3203.

[7] Rajamohan, S., and Vijayaragavan, T, "Production Performance of Madras Cement Limited and that of all Cement Units in India-NA Comparative Analysis", The Management Accountant, Vol.43, Issue. 4, 2008, pp. 264-265.

[8] Shinde C.M., and Priyanka zanvar, "An Empirical Study on Factors Influencing in Investment Decision Making in Pune", International Research Journal of Management and Commerce", Vol. 1, Issue. 6, 2014, pp. 10-23.

[9] Vaijayanthimala, P., and Vijayakumar, A., "Analysis of Operating Performance of Indian Cement Industry", International Journal of Innovative Research and Development, Vol. 3, Issue. 5, 2014, pp. 88-100.

[10] Vijaya, E., "Influential Factors on Investment Behaviour of Individual Investors: A Review of Empirical Evidences from Various Countries", International Research Journal of Management and Commerce, Vol. 1, Issue. 5, 2014, pp. 35-46.

[11] S. Kala, "Impact of Corporate Announcements on Individual Investor's Investment Behavioural Pattern", International Journal of Advanced Research in Management (IJARM), Volume 2, Issue 1, July-December (2011), Pp. 01-09.

[12] Vimal Priyan, J., and Kathihai Selvi, V., "Cement Production: Room for Growth", Facts for You, Vol.1, Issue. 4, 2010, pp. 142-161. 